\section{穴 Heighten Science \\ P U B L I C I T I O N S Corporation \\ ISSN \\ 2573-7708}

\title{
Recurrent Peripheral Ameloblastoma of the Mandible: A Case Report
}

\author{
Angela Jordão Camargo*, Mayara Cheade, Celso Martinelli \\ and Plauto Christopher Aranha Watanabe \\ Department of Stomatology, Public Oral Health and Forensic Dentistry, Ribeirão Preto Dental \\ School, University of São Paulo, Ribeirão Preto, SP, Brazil
}

*Address for Correspondence: Angela Jordão Camargo, Department of Stomatology, Public Oral Health and Forensic Dentistry, Ribeirão Preto Dental School, University of São Paulo, SP, Brazil, Zip Code 14040-904; Email: dra.angelacamargo@ gmail.com; angela.camargo@usp.br

Submitted: 15 November 2016

Approved: 27 January 2017

Published: 30 January 2017

Copyright: @ 2017 Camargo AJ, et al. This is an open access article distributed under the Creative Commons Attribution License, which permits unrestricted use, distribution, and reproduction in any medium, provided the original work is properly cited.

\section{ABSTRACT}

Ameloblastoma is the second most common odontogenic tumor being back only for the odontoma. An unusual case of recurrent peripheral ameloblastoma in the mandible from the site of previous occurrence, reducing oropharyngeal space due compression by lesion. Panoramic radiography not showed presence of lesion, except one step in left side of mandible angle. Multislice CT scans revealed presence of hypoattenuated image, well-defined, histopathological exam suggesting Ameloblastoma Follicular.

\section{INTRODUCTION}

Peripheral ameloblastoma (PA) occurs in soft tissues and is an epithelial odontogenic tumor composed of odontogenic epithelium without participation of odontogenic ectomesenchyme, can be arise from rests of dental lamina, from a developing enamel organ, from the epithelial lining of an odontogenic cyst [1], and the basal cells of gingival epithelium [2].

This report brings an unusual case of recurrent mandibular peripheral ameloblastoma and emphasizes the importance of the correct selection of imaging exams.

The most common tumors are odontomas followed by ameloblastoma, adenomatoid odontogenic tumor and calcifying epithelial odontogenic tumor [3].

\section{CASE REPORT}

Female patient, 45 years old, leucodermic, reported in anamneses have been subjected to two operations for removing peripheral ameloblastoma in the left mandible. Clinical examination revealed increase in volume, well-defined fibrous consistency in the submandibular region, supra and infra hyoid and the floor of the oral cavity to the left, however asymptomatic (Figure 1).

Panoramic radiography not showed presence of lesion, except one step in left side of mandible angle / base (Figure 2). Multislice CT scans revealed presence of hypoattenuated image, well-defined measuring $5.5 \times 5.6$ × $6.8 \mathrm{~cm}$, densities compatible with fibrous tissue and presenting inside hypoattenuated images of different sizes and shapes densities suggestive of cystic cavities (Figure 3). It was also observed a reduction in oropharyngeal space due compression by lesion. The paraxial cuts revealed no intra-osseous lesion, confirming findings of Panoramic Radiography. 


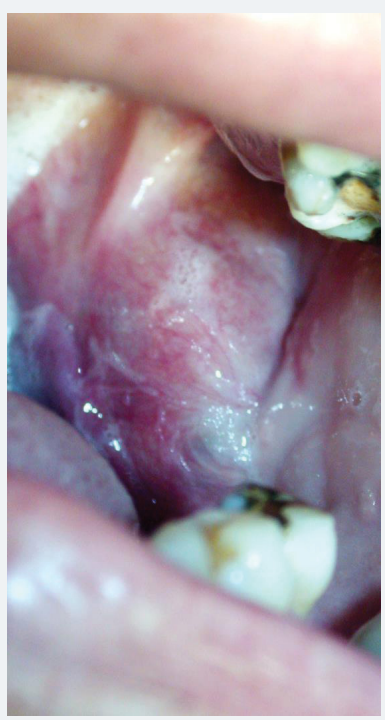

Figure 1: Clinical examination revealed increase in volume, well-defined fibrous consistency in the retromola triangle region, supra and infra hyoid and the floor of the oral cavity to the left mandible, however asymptomatic.

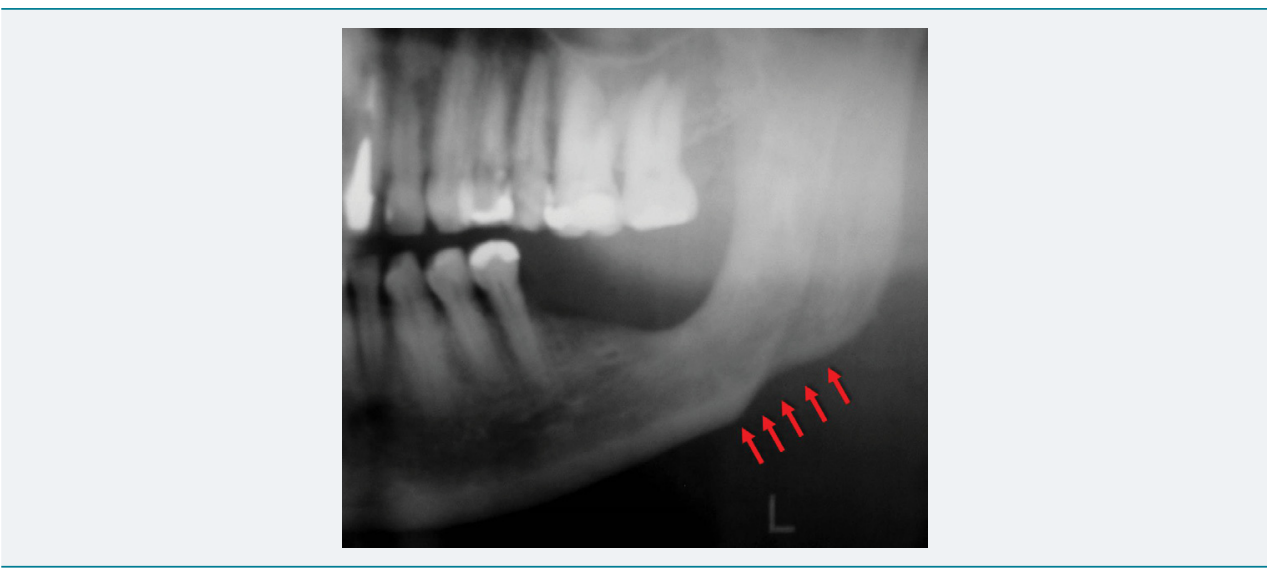

Figure 2: Panoramic radiography not showed presence of lesion, except one step in left side of mandible angle / base (pointed by arrow).

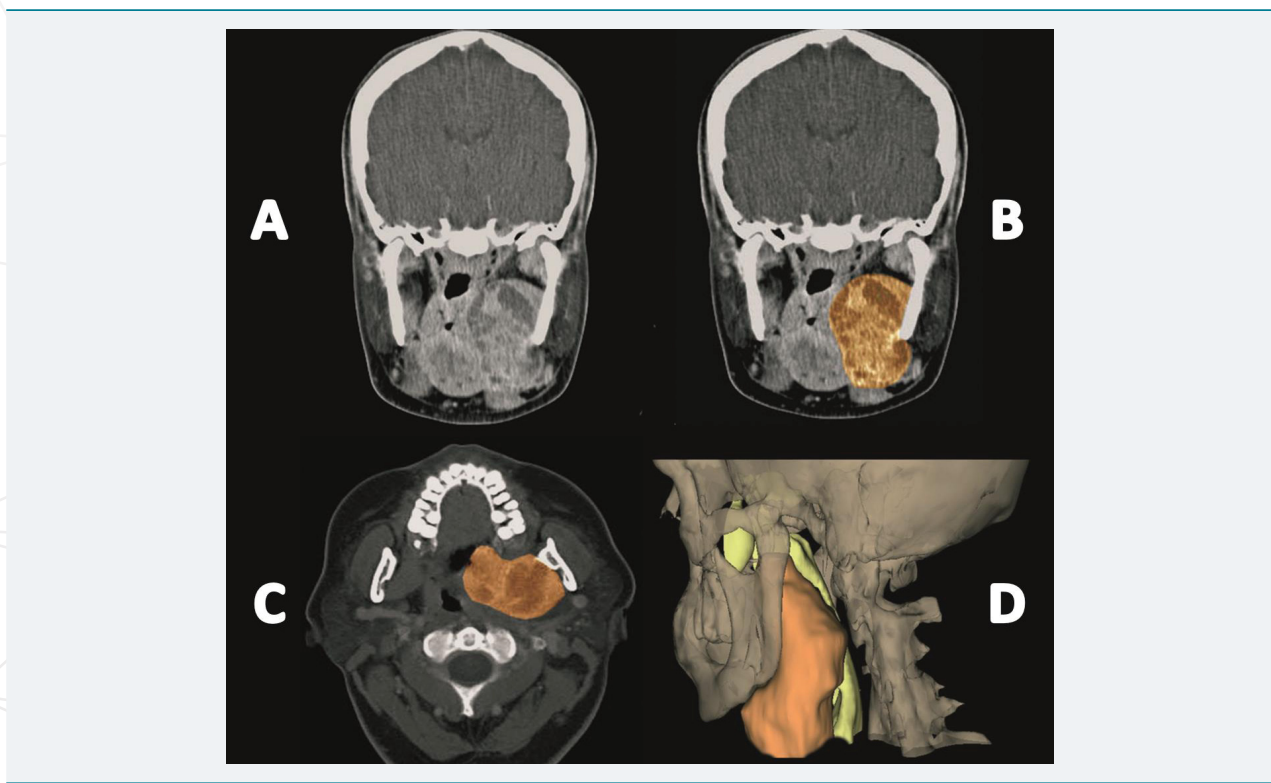

Figure 3: (A) Coronal CT showed lesion in the left side of the mandible; (B) Lesion highlighted in orange; (C) Axial CT with lesion highlighted in orange; (D) 3D Reconstruction showed lesion in the left side of the mandible. 
Material sent for examination consisted of three fragments of soft tissue of irregular shapes and surfaces, fibrous consistencies, brown stains and measuring in all $1.9 \mathrm{x}$ 0.7 x $0.5 \mathrm{~cm}$ (Figure 4). The microscopy from a larger fragment was represented by keratinized squamous epithelial tissue with vacuolar degenerations, covering fibrous connective tissue that exhibits chronic inflammatory reaction, extensive areas of hemorrhage and mucosal salivary glands (hematoma). The two smaller fragments exhibited fibrous connective tissue, transverse cuts and thick bundles of nerve; chronic inflammatory infiltrate and nodular formations of epithelial cells with clear basement membrane, basal and palisade columnar basal cells resembling the starry reticulum of the enamel organ, suggesting follicular ameloblastoma (Figure 5).

\section{DISCUSSION}

Ameloblastoma can be classify in four types, the first one solid /multicystic type is the second most common odontogenic tumor and occurs exclusively in the jaws ( $80 \%$ occur in the mandible). The second one desmoplastic type is a variant of ameloblastoma with specific clinical, imaging and histological features and is found predominantly in the anterior mandibular region. The third one unicystic type represents an ameloblastoma variant, presenting as a cyst, more than $90 \%$ of cases involve the mandible and the forth, extraosseous or peripheral type (PA) [4].

PA has histologic characteristics of an intraosseous ameloblastoma but it occurs in the soft tissues overlying the tooth bearing areas of the maxilla and the mandible [3-5]. Comprises 1.3-10\% of all ameloblastomas. In $64 \%$ of all cases occurring in the fifth and seventh decade. Affects more male (male:female ratio is 1.9:1) and mandible (mandible:maxilla ratio of 2.4:1) [4].

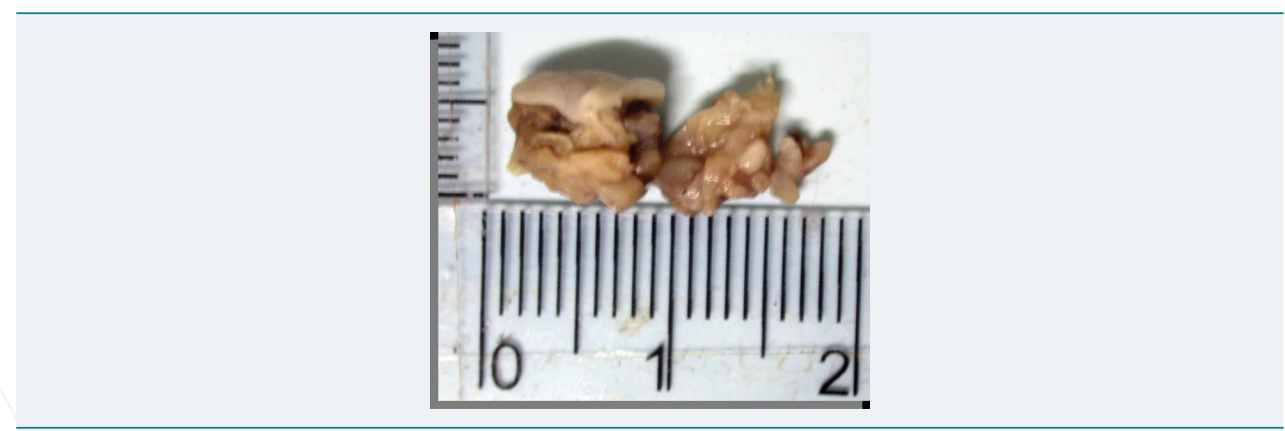

Figure 4: Material sent for examination consisted of three fragments of soft tissue of irregular shapes and surfaces, fibrous consistencies, brown stains and measuring in all $1.9 \times 0.7 \times 0.5 \mathrm{~cm}$.

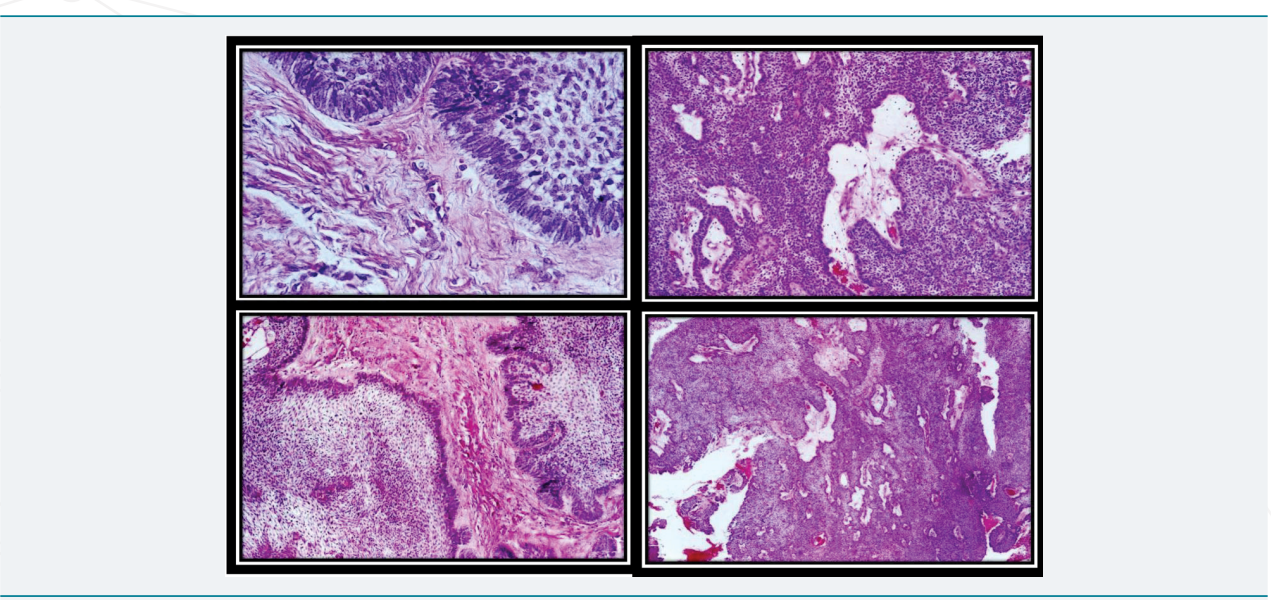

Figure 5: Basaloid - Basal cell follicular; the microscopy was represented by keratinized squamous epithelial tissue with vacuolar degenerations, covering fibrous connective tissue that exhibits chronic inflammatory reaction, extensive areas of hemorrhage (hematoma) and mucosal salivary glands. 
In general, PA is a painless, sessile, firm, and exophytic growth, can be described as granular or pebbly and there is no radiological evidence of bone involvement, can be showed a small superficial erosion of the bone or a superficial bony depression [6].

Cone-Bean Computed Tomography (CBCT) is the most commonly used tomography in dentistry. In this case was not indicated because involved soft tissue. Therefore, a correct analysis of panoramic radiograph (absence of bone lesion) should be an alert for lesions in non-osseous region and the ideal examination with a Multislice CT.

Recurrent PA develop from the general site of the original lesion and is a possible sign of incomplete removal rather than aggressiveness. The prognosis in general is good. Cortical bone of the jaws represents a strong barrier against to invasion of PA. [6]. The treatment should be excision of the lesion with a small margin of normal tissue and the surgical site re-examined periodically [5].

In conclusion, this rare case of recurrent mandibular peripheral ameloblastoma highlight the importance of the correct selection of imaging diagnosis exams. Multislice CT, different from CBCT (dental tomography), allowed the precise visualization of soft tissue lesion and histopathological examination was fundamental for the definitive diagnosis of pathology.

\section{REFERENCES}

1. Pekiner FN, Özbayrak S, Sener BC, Olgaç V, Sinanoglu A. Peripheral ameloblastoma: a case report. Dentomaxillofacial Radiology. 2007; 36: 183-186. Ref.: https://goo.gl/dgKtaK

2. Ide F, Mishima K, Miyazaki Y, Saito I, Kusama K. Peripheral ameloblastoma in-situ: an evidential fact of surface epithelium origin. Oral Surg Oral Med Oral Pathol Oral Radiol Endod. 2009; 108: 763767. Ref.: https://goo.gl/2eiwKS

3. Buchner A, Sciubba JJ. Peripheral epithelial odontogenic tumors: A review. Oral Surc Oral Med Oral Pathol. 1987; 63: 688-697. Ref.: https://goo.gl/0amlEz

4. Barnes L, Eveson JW, Reichart P, Sidransky D. World Health Organization Classification of tumours: pathology and genetics of head and neck tumors. IARC Press. 2005; 297-298.

5. Gardner DG. Peripheral ameloblastoma: a study of 21 cases, including 5 reported as basal cell carcinoma of the gingiva. Cancer. 1977; 39: 1625-1633. Ref.: https://goo.gl/gF2MWf

6. Philipsen HP, Reichart PA, Nikai H, Takata T, Kudo Y. Peripheral ameloblastoma: biological profile based on 160 cases from the literature. Oral Oncology. 2001; 37: 17-27. Ref.: https://goo.gl/LfBtfL 